\title{
Dampak Perilaku Makan Terhadap Kejadian Pre Eklamsia pada Ibu Hamil
}

\author{
Yetty Wilda \\ Poltekkes Kemenkes Surabaya; yetiregina@gmail.com
}

\begin{abstract}
Preeclampsia (PE) is a contributor to maternal and infant mortality and morbidity. Preeclampsia is the second largest cause of maternal death, affecting 3\% to $8 \%$ of pregnant women worldwide. The prevalence of preeclampsia in pregnant women in Magetan Regency in 2017 is 189 people, while in 2018 there are 270 people. An increase in the incidence of preeclampsia from 2017 to 2018 is as many as 81 people. The purpose of this study was to analyze the risk of eating behavior during pregnancy to the incidence of preeclampsia at the Panekan Health Center in 2018. This study was an observational analytic study with a retrospective approach (case control). The subjects of this study were maternity mothers, 27 respondents in the case group and 27 respondents in the control group, so the total was 54 respondents. Data collection was carried out using a questionnaire, carried out on maternal in the working area of Panekan Health Center in 2018. The analysis technique used was logistic regression. The results of the study using logistic regression of eating behavior obtained $p=0.00(p<0.05)$ and OR $(\operatorname{Exp} B)=35.714$. Based on the description above it can be concluded that eating behavior influences the incidence of preeclampsia. Pregnant women who have unhealthy eating behaviors have a 35 times greater risk of experiencing preeclampsia than pregnant women who have healthy eating behaviors, so it is advisable to reduce the incidence of preeclampsia in pregnant women needed to control the risk factors for preeclampsia in pregnancy by implementing healthy eating behavior.
\end{abstract}

Keywords: preeclampsia; eating behavior

\begin{abstract}
ABSTRAK
Preeklamsia (PE) merupakan penyumbang mortalitas dan morbiditas ibu dan bayi. Preeklamsia adalah penyebab terbesar kedua kematian ibu, mempengaruhi 3\% sampai $8 \%$ wanita hamil di seluruh dunia. Prevalensi kejadian preeklamsia pada ibu hamil di Kabupaten Magetan tahun 2017 sebanyak 189 orang, sedangkan pada tahun 2018 sebanyak 270 orang. Terjadi peningkatan angka kejadian preeklamsia dari tahun 2017 ke tahun 2018 yaitu sebanyak 81 orang. Tujuan penelitian untuk menganalisis risiko perilaku makan selama hamil terhadap kejadian preeklamsia di Puskesmas Panekan Tahun 2018. Penelitian ini merupakan penelitian observasional analitik dengan pendekatan retrospektif (case control). Subjek penelitian ini adalah ibu bersalin, 27 responden pada kelompok kasus dan 27 responden pada kelompok kontrol, sehingga totalnya 54 responden. Pengumpulan data dilakukan dengan menggunakan kuesioner, dilakukan pada ibu bersalin di wilayah kerja Puskesmas Panekan Tahun 2018. Teknik analisis yang digunakan adalah logistic regression.Hasil penelitian menggunakan logistic regression perilaku makan didapatkan nilai $\mathrm{p}=0,00(\mathrm{p}<0,05)$ dan OR $(\operatorname{Exp} \mathrm{B})=35,714$. Berdasarkan uraian diatas dapat disimpulkan bahwa perilaku makan berpengaruh terhadap kejadian preeklamsia. ibu hamil yang mempunyai perilaku makan tidak sehat mempunyai risiko 35 kali lebih besar akan mengalami preeklamsia daripada ibu hamil yang mempunyai perilaku makan sehat, sehingga disarankan untuk menurunkan angka kejadian Preeklamsia pada ibu hamil diperlukan pengendalian faktor risiko preeklamsia dalam kehamilan yakni dengan menerapkan perilaku makan sehat.
\end{abstract}

Kata kunci: preeklamsia; perilaku makan

\section{PENDAHULUAN}

\section{Latar Belakang}

Preeklamsia (PE) merupakan penyumbang mortalitas dan morbiditas ibu dan bayi. Preeklamsia adalah penyebab terbesar kedua kematian ibu, mempengaruhi 3\% sampai $8 \%$ wanita hamil di seluruh dunia. Hampir 
$18 \%$ dari kematian ibu karena preeklamsia sebagian besar terjadi di negara berkembang ${ }^{(1)}$. Preeklamsia merupakan salah satu masalah kesehatan yang sering terjadi pada kehamilan. Preeklamsia didefinisikan sebagai peningkatan tekanan darah yang disertai dengan tanda gejala hipertensi dan peningkatan protein urin yang biasanya terjadi pada kehamilan TM III. Jika tidak segera mendapatkan penanganan awal, preeklamsia bisa berlanjut menjadi eklamsia ${ }^{(1,2)}$. Di indonesia, hipertensi merupakan penyebab pertama tingginya kematian ibu. Tahun 2015 AKI menjadi 305/100.000 KH. Pada tahun 2024 ditargetkan AKI turun menjadi 232/100.000 KH. Persentase penyebab kematian ibu diketahui sebesar 33,07\% hipertensi, 27,03\% perdarahan, 15,7\% komplikasi non obstetric, $12,04 \%$ komplikasi obstetric, $6,06 \%$ infeksi dan 4,81\% lain-lain ${ }^{(3,4)}$. Prevalensi kejadian preeklamsia di Jawa timur tahun 2018 sebesar 31\% atau sebanyak 163 orang. Hal ini cenderung meningkat dibandingkan dengan kejadian preeklamsia pada tahun 2017 sebesar 28,92\% atau sebanyak 153 orang. Sedangkan AKI di Jawa Timur pada tahun 2018 mengalami penurunan dari tahun sebelumnya, dari 529 orang menjadi 522 orang $^{(5,6)}$. Preeklamsia merupakan penyumbang kedua kematian ibu. Persentase penyebab kematian ibu di Jawa Timur tahun 2018 diketahui penyebab lain-lain yaitu 32\% atau 170 orang, Pre Eklamsi / Eklamsi yaitu sebesar $31 \%$ atau sebanyak 163 orang dan perdarahan yaitu 23\% atau sebanyak 119 orang, jantung $10 \%$ atau 51 orang. Sedangkan penyebab paling kecil adalah infeksi sebesar 4\% atau sebanyak 19 orang (6). Berdasarkan studi pendahuluan dari data LB3KIA, prevalensi kejadian preeklamsia pada ibu hamil di Kabupaten Magetan tahun 2017 sebanyak 189 orang. Sedangkan pada tahun 2018 sebanyak 270 orang. Hal ini menunjukkan bahwa terjadi peningkatan angka kejadian preeklamsia dari tahun 2017 ke tahun 2018 yaitu sebanyak 81 orang. Kejadian tertinggi di wilayah Puskesmas Panekan sebanyak 27 orang. Preeklamsia menjadi penyebab kematian kedua setelah perdarahan yaitu sebanyak 2 orang meninggal karena preeklamsia atau sebesar $15,38 \%$ per $100.000 \mathrm{KH}^{(3,4)}$.

Faktor penyebab Preeklamsia adalah status kesehatan ibu, status reproduksi, status gizi, akses ke pelayanan kesehatan dan perilaku kesehatan ${ }^{(7)}$. Perilaku kesehatan merupakan suatu respon terhadap rangsangan. Perilaku kesehatan terdiri dari 3 aspek salah satunya perilaku gizi/ perilaku makan. Dampak yang bisa dialami ibu hamil dengan preeklamsia ada 2 yaitu dampak bagi janin dan bagi ibu sendiri. Bagi janin dapat menyebabkan gangguan pertumbuhan (IUGR), kematian janin dalam kandungan (IUFD), BBLR. Sedangkan dampak bagi ibu adalah ibu menjadi tidak sadar (koma) sampai meninggal ${ }^{(2,8)}$.

Besarnya pengaruh preeklamsia terhadap tingginya kematian ibu dan banyaknya dampak dari preeklamsia terhadap kesehatan ibu, maka perlu dilakukan upaya untuk mencegah dan menangani kasus-kasus preeklamsia. Strategi pemerintah dalam menurunkan Angka Kematian Ibu di Indonesia ${ }^{(7,8)}$ adalah melalui strategi intervensi yang terdiri dari empat hal utama yaitu peningkatan akses pelayanan kesehatan, peningkatan kualitas pelayanan kesehatan, pemberdayaan masyarakat dan penguatan tata kelola. Strategi tersebut meliputi pelayanan ANC berkualitas sesuai standart $10 \mathrm{~T}$, ibu hamil dan bersalin di fasilitas kesehatan, ANC dan PNC yang berkualitas, deteksi dini, sistem rujukan yang terintegrasi serta RS sayang ibu dan bayi ${ }^{(9,10)}$.

\section{Tujuan Penelitian}

Tujuan penelitian ini adalah 1.Mengidentifikasi karakteristik ibu hamil dari usia, paritas, pekerjaan dan pendidikan.2.Mengidentifikasi perilaku makan dari kelompok yang menderita preeklamsia 3.Mengidentifikasi perilaku makan dari kelompok yang tidak menderita preeklamsia 4.Menganalisis pengaruh perilaku makan selama hamil terhadap kejadian preeklamsia.

\section{Hipotesis}

Hipotesis peneitian ini adalah hipotesis pada penelitian ini adalah : perilaku makan selama hamil berpengaruh terhadap kejadian preeklamsia.

\section{METODE}

Penelitian ini menggunakan rancangan case control dengan perbandingan 1:1. Case control merupakan suatu penelitian (survey) analitik yang menyangkut bagaimana faktor risiko dipelajari dengan menggunakan pendekatan restropective ${ }^{(11,12)}$. Populasi pada penelitian ini adalah populasi seluruh ibu bersalin di Puskesmas Panekan tahun 2018. Sampel pada penelitian ini pada kelompok kasus adalah semua ibu bersalin dengan riwayat preeklamsia dan pada kelompok kontrol adalah sebagian ibu bersalin yang tidak mempunyai riwayat 
preeklamsia. Pada penelitian ini menggunakan ukuran sampel pada kelompok kasus sebanyak 27 ibu bersalin yang mempunyai riwayat preeklamsia di Puskesmas Panekan. Ukuran sampel pada kelompok kontrol sebanyak $27 \mathrm{ibu}$ bersalin yang tidak mengalami preeklamsia. Sehingga perbandingan antara kelompok kasus dan kelompok kontrol yaitu 1:1, jadi total sampel sebanyak 54 orang.

Variabel penelitian meliputi variabel bebas adalah perilaku makan, variabel terikatnya adalah kejadian preeklamsia. Instrumen pengumpulan data pada penelitian ini menggunakan lembar dokumen rekam medik dan kuesioner.Analisis statistik meliputi analisis deskriptif dan analitik dengan analisis regresi.

\section{HASIL}

\section{Data Karakteristik Responden pada Kelompok Preeklasmia}

Tabel 1. Distribusi karakteristik responden pada kelompok preeklamsia berdasarkan usia, paritas, pendidikan, dan pekerjaan

\begin{tabular}{|l|c|c|}
\hline \multicolumn{1}{|c|}{ Karakteristik } & Frekuensi & Persentase \\
\hline Usia & 20 & 74 \\
20-35 tahun & 7 & 26 \\
$>35$ tahun & 27 & 100 \\
Total & & \\
\hline Paritas & 7 & 26 \\
Primipara & 20 & 74 \\
Multipara & 27 & 100 \\
Total & & \\
\hline & & \\
Pendidikan & 5 & 18,5 \\
SD & 10 & 37 \\
SMP & 11 & 40,8 \\
SMA sederajat & 1 & 3,7 \\
S1 & 27 & 100 \\
Total & 11 & \\
\hline & & \\
Pekerjaan & & 40,7 \\
IRT & 3 & 29,6 \\
Petani & & 14,9 \\
Wiraswasta & & 11,1 \\
Swasta & & 3,7 \\
Guru & & 100 \\
Total & & \\
& & \\
\hline
\end{tabular}


Tabel 1 tentang karakteristik ibu yang mengalami preeklamsia dilihat dari usia didapatkan hasil sebagian besar responden yang mengalami preeklamsia berusia 20-35 tahun yaitu sebanyak 20 orang (74\%), dilihat dari tingkat paritas antara Primipara dan Multipara lebih banyak Multipara sebanyak 20 orang (74\%), berdasarkan tingkat pendidikan SMA sederajat sebanyak 11 orang $(40,8 \%)$ dan pekerjaan terbanyak responden bekerja sebagai IRT sebanyak 11 Orang $(40,8 \%)$.

\section{Karakteristik Responden pada Kelompok Tidak Preeklamsia}

Tabel 2. Distribusi karakteristik responden pada kelompok tidak preeklamsia berdasarkan usia, paritas, pendidikan, dan pekerjaan di puskesmas panekan tahun 2018

\begin{tabular}{|c|c|c|}
\hline Karakteristik & Frekuensi & Persentase \\
\hline \multicolumn{3}{|l|}{ Usia } \\
\hline 20-35 tahun & 26 & 96,3 \\
\hline$>35$ tahun & 1 & 3,7 \\
\hline Total & 27 & 100 \\
\hline \multicolumn{3}{|l|}{ Paritas } \\
\hline Primipara & 8 & 29,6 \\
\hline Multipara & 19 & 70,4 \\
\hline Total & 27 & 100 \\
\hline \multicolumn{3}{|l|}{ Pendidikan } \\
\hline SD & 3 & 11,1 \\
\hline SMP & 7 & 25,9 \\
\hline SMA sederajat & 17 & 63 \\
\hline Total & 27 & 100 \\
\hline \multicolumn{3}{|l|}{ Pekerjaan } \\
\hline IRT & 9 & 33,3 \\
\hline Petani & 5 & 18,5 \\
\hline Wiraswasta & 11 & 40,7 \\
\hline Swasta & 2 & 7,5 \\
\hline Total & 27 & 100 \\
\hline
\end{tabular}

Berdasarkan hasil penelitian yang dapat dilihat pada table 2 didapatkan hampir seluruhnya responden yang tidak mengalami preeklamsia berusia 20-35 tahun yaitu sebanyak 26 orang (96,3\%), tingkat paritas antara Primipara dan Multipara lebih banyak Mutlipara sebanyak 19 orang (70,4\%), tingkat pendidikan responden lebih dari separuh adalah SMA sederajat sebanyak 17 orang (63\%) dan responden terbanyak bekerja sebagai Wiraswasta sebanyak 11 Orang $(40,7 \%)$. 


\section{Perilaku Makan dengan Kejadian Preeklamsia}

Tabel 3. Distribusi Silang Antara Perilaku Makan Dengan Kejadian Preeklamsia

\begin{tabular}{|c|c|c|}
\hline \multirow{2}{*}{ Perilaku Makan } & \multicolumn{2}{|c|}{ Preeklamsia } \\
\cline { 2 - 3 } & Ya & Tidak \\
\hline Tidak Sehat & $20(74,1 \%)$ & $2(7,4 \%)$ \\
\hline Sehat & $7(25,9 \%)$ & $25(92,6 \%)$ \\
\hline Total & $27(100 \%)$ & $27(100 \%)$ \\
\hline
\end{tabular}

Hasil distribusi silang menunjukkan ibu yang mengalami preeklamsia dari paparan perilaku makan tidak sehat sebanyak $74,1 \%$. Tidak preeklamsia tetapi terpapar perilaku makan tidak sehat sebanyak $7,4 \%$.

\section{Perbedaan Perilaku Makan Kelompok Preeklamsia dan Tidak Preeklamsia Berdasarkan Hasil Kuesioner}

Tabel 4. Perbedaan perilaku makan

\begin{tabular}{|c|c|c|}
\hline Kuesioner & Preeklamsia & Tidak Preeklamsia \\
\hline 1. Makanan atau minuman manis & 1x perhari & 3-6x perminggu \\
\hline 2. Makanan asin & $1 \mathrm{x}$ perhari & 3-6x perminggu \\
\hline $\begin{array}{l}\text { 3. Makanan berlemak / } \\
\text { berkolesterol/gorengan }\end{array}$ & $1 \mathrm{x}$ perhari & 3-6x perminggu \\
\hline 4. Makanan yang dibakar & $<3 x$ perbulan & Tidak pernah \\
\hline $\begin{array}{l}\text { 5. Makanan daging / ayam / ikan olahan } \\
\text { dengan pengawet }\end{array}$ & $3-6 x$ perminggu & Tidak pernah \\
\hline 6. Bumbu penyedap & $1 \mathrm{x}$ perhari & 1x perhari \\
\hline 7. Kopi & $>1 \mathrm{x}$ perhari & Tidak pernah \\
\hline $\begin{array}{l}\text { 8. Minuman berkafein buatan bukan } \\
\text { kopi }\end{array}$ & $3-6 \mathrm{x}$ perminggu & Tidak pernah \\
\hline 9. Mie instan / mie basah & $3-6 x$ perminggu & $<3 \mathrm{x}$ perbulan \\
\hline 10. Roti/biskuit & 1x perhari & $3-6 x$ perminggu \\
\hline
\end{tabular}

Hasil penelitian menunjukkan ada beda perilaku makan pada ibu dengan preeklamsia dengan yang tidak preeklamsia. Ibu yang mengalami preeklamsia sering mengkonsumsi makanan yang tidak sehat dibandingkan dengan ibu yang tidak menderita preeklamsia. 


\section{PEMBAHASAN}

\section{Kejadian Preeklamsia Ibu Berdasarkan Usia}

Hasil penelitian menunjukkan bahwa ibu berdasarkan usia pada ibu preeklamsia dan tidak preeklamsia menunjukkan persamaan yaitu mayoritas responden berusia 20-35 tahun. Namun, hampir separuh ibu preeklamsia terjadi pada usia $>35$ tahun. Disebutkan insiden tertinggi kasus preeklamsia terjadi pada usia remaja atau awal usia 20 tahun, tetapi prevalensinya meningkat pada wanita diatas 35 tahun $^{(7)}$. Keterangan lain dijelaskan bahwa usia terlalu muda atau terlalu tua merupakan faktor terjadinya preeklamsia. Usia kurang dari 20 tahun sangat beresiko karna belum matangnya alat reproduksi untuk hamil, dan > 35 tahun fungsi organ reproduksi juga mulai mengalami penurunan sehingga tidak dapat bekerja secara maksimal. Ibu yang berumur kurang dari 20 tahun dan lebih 35 tahun berpotensi 3x lipat terkena preeklamsia dibandingkan dengan ibu hamil yang berusia 20-35 tahun. Namun kenyataannya, pada hasil penelitian ini usia ibu yang tidak beresiko juga memberikan banyak sumbangsih terhadap kejadian preeklamsia ${ }^{(12,13)}$. Hasil penelitian ini juga sejalan dengan penelitian yang dilakukan di ruang Kebidanan RSUP Dr.M. Djamil Padang Tahun 2016 menunjukkan bahwa umur ibu hamil sebagian besar tidak beresiko pada preeklampsia dan sebagian kecil umur ibu hamil yang beresiko terhadap pre-eklampsia ${ }^{(8)}$. Penelitian,lain menyebutkan prevalensi kejadian preeklamsia pada ibu yang berusia 20-35 tahun masih tinggi, untuk itu disarankan ibu hamil melakukan pemeriksaan ANC yang rutin agar deteksi dini preeklamsia dapat dilakukan. Sehingga, kematian dan kesakitan ibu karena preeklamsia dapat dicegah ${ }^{(14)}$.

\section{Kejadian preeklamsia Ibu Berdasarkan Paritas}

Hasil penelitian berdasarkan paritas ibu yang mengalami preeklamsia dan tidak preeklamsia hampir separuhnya terjadi pada Primipara dan sebagian besar terjadi pada. Hal ini menunjukkan bahwa kejadian preeklamsia terbanyak terjadi pada ibu multipara. Hasil penelitian ini sejalan dengan penelitian yang dilakukan oleh Pandiangan J.M dan Kusnanto H (2017) yaitu sebanyak 25,23\% preeklamsia terjadi pada primipara, sedangkan pada multipara sebanyak 35,51\%. Penelitian menunjukkan bahwa paritas ibu yang mengalami preeklamsia lebih banyak terjadi pada multipara daripada primipara.Prevalensi kejadian peeklamsia dari hasil penelitian sebelumnya didapatkan hasil mayoritas ibu hamil yang megalami preklamsia adalah multipara. Hal ini berbeda dengan dengan penelitian lain yang menyatakan bahwa primipara merupakan faktor resiko terjadinya preeklamsia dikarenakan pada penelitian ini didapatkan ibu yang mengalami preeklamsia kebanyakan terjadi pada multipara, ${ }^{(7)}$. Berdasarkan hasil penelitian, peneliti menyimpulkan bahwa preeklamsia dapat terjadi pada ibu Primipara maupun Multipara. ibu Primipara maupun Multipara sama-sama mempunyai resiko untuk mengalami preeklamsia. Oleh karena itu, disarankan Bidan dapat memberikan pelayanan ANC yang berkwalitas dan bidan dapat melakukan screening preeklamsia, sehingga diagnosa preeklamsia dapat ditemukan sedini mungkin.

\section{Kejadian Preeklamsia Ibu Berdasarkan Pendidikan}

Hasil penelitian mengenai karakteristik ibu yang mengalami preeklamsia dan tidak preeklamsia berdasarkan pendidikan didapatkan hasil pendidikan ibu banyak adalah tingkat pendidikan SMA.Pendidikan seseorang berhubungan dengan kesempatan menyerap informasi mengenai pencegahan dan faktor-faktor risiko preeklamsia. Tetapi pendidikan ini akan dipengaruhi oleh seberapa besar motivasi, atau dukungan lingkungan seseorang untuk menerapkan pencegahan dan faktor risiko preeklamsia ${ }^{(8,18)}$. Hasil penelitian sebelumnya juga didapatkan hasil bahwa sebagian ibu yang mengalami preeklamsia berpendidikan SMA. Seperti pada penelitian yang dilakukan oleh Pandiangan J.M dan Kusnanto H (2017) da penelitian yang dilakukan oleh Taslim R.W.R, dkk (2016) juga didapatkan hasil mayoritas responden berpendidikan SMA. Hasil penelitian ini bertolak belakang dengan hasil penelitian yang menyatakan bahwa ibu yang status pendidikannya rendah (tidak sekolah, SD, SMP) beresiko mengalami preeklamsia ${ }^{(16)}$. 


\section{Karakteristik Ibu Berdasarkan Pekerjaan}

Hasil penelitian didapatkan hasil hampir separuhnya ibu yang mengalami preeklamsia tidak bekerja (IRT). Sedangkan pada kelompok ibu yang tidak mengalami preeklamsia didapatkan hasil terbanyak adalah ibu bekerja sebagai wiraswasta. Hasil penelitian ini dikuatkan dengan hasil penelitian lain yang menyatakan bahwa pekerjaan mempengaruhi tingkat stress yang memicu timbulnya hipertensi dan dapat meningkatkan resiko terjadinya preeklamsia,(18,19). Hal ini sebabkan karena ibu yang tidak bekerja akan merasakan stres yang mungkin dirasakan setiap hari karena kurangnya kegiatan diluar rumah yang membuat ibu hamil sering bosan, oleh karena itu bidan perlu memberikan penyuluhan kepada ibu hamil untuk sesering mungkin melakukan kegiatan diluar rumah misalnya berjalan-jalan setiap pagi hari, mengikuti kelas ibu hamil, dan rekreasi setiap sudah mulai merasa bosan didalam rumah.

\section{Pengaruh Perilaku Makan Selama Hamil Terhadap Kejadian Preeklamsia}

Hasil penelitian ini bu hamil yang mempunyai perilaku makan tidak sehat mempunyai resiko 35x lebih besar akan mengalami preeklamsia daripada ibu hamil yang mempunyai perilaku makan sehat. Penelitian lain menyebutkan bahwa perilaku asupan zat gizi/ pada ibu hamil, kebiasaan mengonsumsi makanan tinggi lemak dan tinggi garam, ketidakseimbangan menu makanan akan membentuk stress oksidatif dapat menyebabkan terjadinya pre eklamsia selama kehamilan, ${ }^{(9,15,16,17)}$.

Ibu hamil memerlukan makan yang mempunyai kelengkapan gizi hal ini penting terutama pada umur kehamilan 20 minggu, pada saat ini sebaiknya ibu hamil tidak mengkonsumsi nutrisi yang tinggi natrium dan rendah protein karena dapat menyebabkan gangguan kehamilan seperti pre-eklamsi. Dampak dari gangguan pola nurisi selama kehamilan bisa berakibat dengan semakin meningkatnya angka kejadian pre-eklamsi yang ditandai dengan gejala tekanan darah tinggi, kelebihan kadar protein pada urin, edema kaki, penglihatan kabur, sesak nafas dan menurunnya kesadaran dan kejang. Berdasarkan hasil penelitian diatas peneliti berpendapat bahwa perilaku makan selama hamil berpengaruh pada status kesehatan ibu yang akan meningkatkan angka kesakitan ibu hamil, salah satunya yaitu karena preeklamsia ${ }^{(17,18)}$.

\section{KESIMPULAN}

Kesimpulan hasil penelitian ini adalah bahwa riwayat ibu hamil yang mengalami preeklamsia ada beberapa hal latar belakang dari iu amil tersebut diantaranya kelompok usia, tingkat paretas, latar belakang peendidikan serta riwayat pendidikan.Tentang riwayat pola makan pada kelompok Ibu hamil dengan pola makan yang sehat tingkat insiden preeklamsi lebih rendah disbanding ibu dengan pola makan yang tidak sehat. Ibu hamil dengan perilaku makan yang tidak sehat lebih beresiko lebih tinggi dalam kejadian preeklamsia dibandingkan dengan ibu hamil dengan perilaku makan sehat.

\section{DAFTAR PUSTAKA}

1. Omran, et al. Prediction of Preeclampsia with Novel Biomarkers at Second Trimester of Pregnancy. Journal of Clinical \& Cellular Immunology. 2016;7(3):1-6.

2. Astuti S, et al. Asuhan Ibu Dalam Masa Kehamilan. Jakarta: Erlangga; 2017.

3. Dinkes Kab. Magetan. LB3KIA: Laporan Maternal. Magetan: Dinkes Kab. Magetan; 2017.

4. Dinkes Kab. Magetan. LB3KIA: Laporan Maternal. Magetan: Dinkes Kab. Magetan; 2018.

5. Pritasari K. Strategi Akselerasi Penurunan Angka Kematian Ibu dan Bayi Baru Lahir. Makalah disajikan pada Rapat Kerja Nasional, Direktorat Jenderal Kesehatan Masyarakat, Kemenkes RI. Tangerang: Direktorat Jenderal Kesehatan Masyarakat, Kemenkes RI; 2017.

6. Kemenkes RI. Profil Kesehatan Indonesia Tahun 2017. Jakarta: Kemenkes RI; 2017.

7. Saifuddin. Ilmu Kebidanan. Jakarta: PT. Bina Pustaka Sarwono Prawirohardjo; , 2014.

8. Transyah $\mathrm{CH}$. Hubungan Umur dan Paritas Ibu Bersalin dengan Kejadian Preeklamsia. Jurnal Human Care. 2018;3(1).

9. Wafiyatunisa Z, Rodiani. Hubungan Obesitas dengan Terjadinya Preeklamsia. Majority. 2016;5(5):184190. 
10. Widyatama A. Cegah preeklamsia saat hamil dengan makanan ini. 2017. Available from: https://www.klikdokter.com/info-sehat/read/3155372/cegah-preeklamsia-saat hamil-dengan-makanan-inii

11. Nursalam. Metodologi Penelitian Ilmu Keperawatan. Jakarta: Salemba Medika; 2017.

12. Notoatmodjo S. Metodologi Penelitian Kesehatan. 2012; Jakarta: Rineka Cipta.

13. Manuaba. Ilmu Kebidanan Penyakit Kandungan dan KB. Jakarta: EGC; 2010.

14. Wulandari N, Astuti D, Sumarni. Hubungan Konsumsi Makanan Sumber Antioksidan dan Konsumsi Makanan Kaleng Dengan Kejadian Preeklampsia di Rsud Dr. R. Goeteng Taroenadibrata Purbalingga Tahun 2015. Jurnal Ilmiah Kebidanan. 2015;6(2):85-93.

15. Retnawati SA, Suryanti S. Hubungan Antara Usia, Paritas Dan Perilaku Asupan Zat Gizi Dengan Kejadian Pre Eklampsia pada Ibu Hamil di RSUD Provinsi Kepri Tahun 2017. Jurnal Cakrawala Kesehatan. 2017;8(1):19-33.

16. Rahayu LDP, Suryandari AE. Hubungan Kebiasaan Konsumsi Junk Food Dengan Kejadian Pre Eklampsia Pada Ibu Hamil di RSUD Prof.Dr. Margono Soekarjo. Jurnal Involusi Kebidanan. 2014;4(8):1-10.

17. Taslim, et al. Hubungan Pola Makan dan Stres Dengan Kejadian Hipertensi Grade 1 dan 2 pada Ibu Hamil di Wilayah Kerja Puskesmas Kamonji Kecamatan Palu Barat. E-Journal Keperawatan. 2016;4(1).

18. Sihotang PC, et al. Hubungan Pola Makan dan Kecukupan Istirahat Tidur Dengan Kejadian Hipertensi Pada Ibu Hamil Di Wilayah Kerja Puskesmas Biromaru. Jurnal Kesehatan Tadulako, 2016, Vol 2, No 1, 68-75.

19. Pandiangan J.M dan Kusnanto H. Determinan Preeklamsia pada Ibu Hamil di Bantul. Berita Kedokteran Masyaraka (BKM Journal of Community Medicine and Public Health). 2017;33(9):423-426. 